\title{
Dialectic contradictions of global and local within the city transformations. (Case study of Russian cities)
}

\author{
Irina Kukina \\ Departament of Urban Design and Planning. Siberian Federal University. Krasnoyarsk. Russia \\ E-mail: ikukina@inbox.ru
}

\begin{abstract}
The results of morphological analyses of the urban structures more and more attract attention with the aim of understanding the processes and laws of transformation of the city fabric. Comparison of the case studies representing different regional cultures gives reasons to presume the presence of global trends as well as local features. Their dialectical contradictions lead to a unique urban form very often. Thus, recent global conversion caused very similar urban problems as well as methods for their solution characteristic to the whole world. Popularization rate of the past is comparable to the speed of propagation of a certain fashion lifestyle. As the result - reversal of thinking to find local uniqueness of each settlement and this tendency again step by step became global. From other side universal morphological conceptual apparatus built on factual analysis allows to trace the objective process of urban transformation and to give some forecasts concerning changes in their structure. Assumptions must be considered with the adjustment for the modern scale. Never the less contemporary cities - Krasnoyarsk, Irkutsk demonstrate building and fabric adaptation, redevelopment, additive processes, contrast with transformative processes, agricultural residual (areas of town dachas in Russian urban tradition), augmentative redevelopment, different scales of changes of use, loft-cycle (second, re- use) development, street markets concretion, other, characteristic not only for the historic heritage areas but for the modern city as well. Russian cities in our days demonstrate urban-rural fringe development somewhat even similar to "cocktail-belts" but with the local eclectic Siberian architecture.
\end{abstract}

Keywords: urban structures, global and local reasons for the city transformation, morphological gaps

\section{Introduction}

Since the middle of the XX century in the world professional consciousness a firm position on the value of each historical stage in the development of cities and settlements, preservation of special peculiarity of each of them has been formed. Methodologies, methods of research and conservation of cultural monuments have been formed. However, urban areas of different scale as objects of cultural history, actively functioning with all the complexity of the problems, are mainly subjects of scientific discussions. In historical science, as a rule, architectural objects, established urban ensembles and historical cities of a certain stage of development are studied, but applied research and practical urban planning deals with functional zones, structure and infrastructure of populated areas. The gap within the research approaches could be filled out with the urban morphological methodology.

\section{Methodology}

Since the middle of the XIX century to the 
present time humanity has four times changed the concept of its environment under the pressure of global crises of technological epochs. The city has passed through medieval, industrial, post-industrial stages of development and by definition of a number of researchers "is being immersed into "post-carbon "stage. In each of the eras a specific image, structure of towns and cities, rules of design are being developed. These arguments contain at least three ideas about the development of populated settlements and an urban idea, confirmed by a number of studies. They are also confirmed by new large-scale urban projects implemented at the end of the XX - beginning of the XXI century. We mean conflict-free coexistence in a single urban space of phenomena and systems that are considered incompatible - sort of "parallel":

- overcoming spatial segregation and restructuring of the modern city in connection with the formation of marginal gaps in the process of replacing industrial, energy, information technologies, as well as territories with the incomprehensible morphology for the urban designers and planners;

- the inevitable tendency of combining global and regional beginnings of the modern city, while preserving its cultural identity;

- restoration of aboriginal eco-systems through the functioning of the city and unexhaustion of natural resources (combination of territorial spaces of cultures and biotypes). The latter process requires the development of a fundamentally new view of the regulations of eco-oriented urban renewal, not based on the principle of cost-effective approach to engineering and building complex, but on the contrary, some "spare" abundance, ensuring the vital activity of biological species, especially in the case of anthropogenic crises.

Cultural identity as a social-planning problem has sounded particularly urgent in relation to global phenomena and processes in economics, information technology, an increase in the population mobility, introduction of "the international architectural style" of highrise construction, universalization of the socalled "central business districts" instead of the classical understanding of the city centre. Leaching of regional traditions, way of life, architectural styles, etc. is taking place.
At the same time residential environment of the old town is commonly viewed as a community of integrated "natural areas". A "natural area" - is a concept associated with perception of the residence, visual certainty and perceptibility, a special architectural image, connectivity of the territory with any phenomena, traditions, history of the place. They are also looked at as established resident communities, or the communities that are being established, that is, with the feelings based on a specific quality, its borders, which are regulated by neither the city administration nor the documents of the layout.

Understanding the above-mentioned processes of city development leads to an understanding of the morphological diversity of urban form. As it has been proved in the studies of urban morphology, each of the unique fragments of the city could be identified as a specific landscape unit with a unique history of formation, but close and in interrelation with other morphological units of the city (Conzen, 1969). What, in general, can lead to a more accurate formulation of urban development strategies and conflict-free preservation and development of the uniqueness of each of the landscape unit. The following is no doubt a productive urban morphological concept that can serve to overcome the segregation of the city - if the concept of fringe belts (Conzen, 1960; Whitehand 1967, 1974, 1988; Barke,1976, 1990; Ünlü T., 2013, other)

\section{Measurement and analysis}

Urban ideas in the late XIX - early 30-ies of the XX century in many countries were aimed at finding optimal design solutions for cities, to overcome the crisis of chaotic development and degradation of territories in connection with the emergence and development of industrial production. One of the greatest challenges in this regard was the problem of industrial and residential slum areas, mostly located on the outskirts of the city. Three tendencies of scientific-theoretical urban planning sprang into being. The first was the search for concepts of a "new city", unburdened 
by the marginal slums. It was assumed that margins should carry a new feature - a smooth transition to rural or natural areas. The second tendency consisted in the urban morphological studies based on historical analysis of urban development depending on their physiographic features. The third direction included natural and Earth sciences, exploring the city. Our aim is to consider the results of the influence of global concepts of development of cities and urban processes that has swept into the world and local factors on the formation of unique characteristics of Russian cities, based on the above research areas and morphological classification of the territories.

Siberian cities at the time of design of the first master plans of the Soviet period in the late 30ies of the XX century included residential areas attached to industrial enterprises, workingclass suburbs, suburban areas for recreational and economic purposes, etc., like any other city in the world. Russian historical research highlighted four periods in the history of the origin and development of Siberian cities. The first stage is considered to be the foundation and construction of "ostrog" settlements, carrying out defensive functions in the East of the Russian Empire, with the progress of Russian explorers in the depths of Siberia in the XVII - the first quarter of the XVIII centuries. The second stage covers 1725-1892 from the time of transformation of cities into centers of trade, gold mining, the fur trade and the establishment of their close relationships with the Moscow (Siberian) tract. The third period covers the construction process of the industries and railroad and its impact on urban growth in the 90-ies of the XIX century until 1917. And finally, there is the fourth stage - the Soviet period.

Krasnoyarsk was founded as a military settlement of the first phase of the development of Siberia in 1628. The second focus of settlement was the Bazaikha village - a modern part of the south - western district, and the third area after the city had lost its military importance was named the village of Pokrovskaya on the Karaulnaya Hill. The importance of the Karaulnaya Hill as the focus of landscape relations was recognized from the very beginning of the city's foundation as a viewing point, a reference point, observation post and the architectonic construction of the "body" of the mountain crowned by its chapel. The Krasnoyarsk ostrog settlement was located on the spit of the 3rd flat above valley bottom terrace at the confluence of the main river the Yenisei and its tributary, the "home» river Kacha. The orientation of the West-East cape arrow and almost parallel direction of the Yenisei and Kacha beds defined the natural shape of Krasnoyarsk streets in the type of a lattice, close to "the grid". The city was restricted by an ostrog wall and the channels of two rivers (had artificial/physical and natural borders), and in the West it was protected only by the ostrog wall (artificial/physical border). At the end of XVII century two dramatic moments in the development of the city were fixed, both events being associated with the inclusion of western outlying areas in the plan of the city and review of the status of its borders. The first was associated with the movement of sales outlet rows from Starobazarnaya on to Novobazarnaya Square (later Sobornaya). Novobazarnaya Square (located on the site of modern Revolution Square) was formed on the western side of the city and, in the opinion of the citizens of that time, was not attractive since it was situated on the far "edge" of the city. New outlet rows were larger, taller and took more space, so the townspeople found them cold, uncomfortable and unattractive. It took special measures for the resettlement of merchants to the new trading areas and attraction of new developers to this part of the city. The second episode was associated with the establishment of the municipal garden to the South of Sobornaya Square. Later, Sobornaya Square and the city garden formed a broad strip of vacant space that separated the previously established city from the new development and protected the area against the spread of potential fires, the main danger of Siberian cities in the XIX century. On the other side, the territory became a transitional buffer element from high density buildings of the "old" city to the new architectural scale of Sobornaya Square, where in 1845 - 1861 the main Orthodox Church of Krasnoyarsk and the Yenisei province the Nativity Cathedral by $\mathrm{K}$. Ton was erected. The Bishop's house 


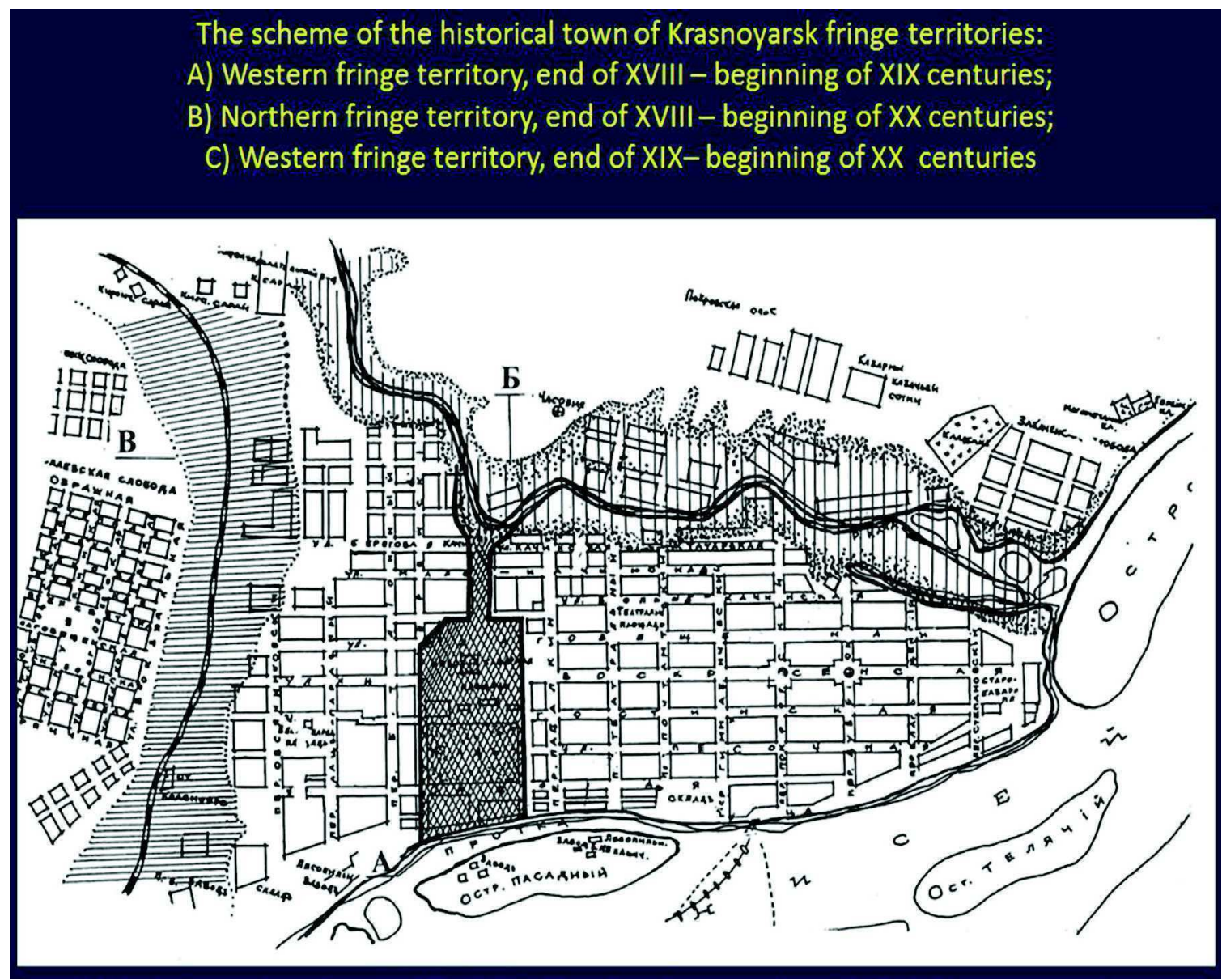

Figure 1.

Scheme of the fringes of Krasnoyarsk

and Seminary building overlooked the square. The western edge of the end of the XYIII century has retained its compositionseparating function to the present time. First, because the eastern part of the historic center has smaller size of neighborhoods in the city plan; it is in this part of the city where coronary intersections have been preserved; secondly, the eastern and western parts are very different in scale, density and style of facades. During the construction of the railway, and as a result of the active construction of the city, the old wooden fund started to be quickly replaced in the "old" city territory, stone buildings up to four floors were being erected of representatives of all architectural styles of the late XIX and the early XX centuries. Development was conducted mainly in the eastern direction from the city garden and Sobornaya Square, while to the west stone buildings appeared only in separate quarters.
Replacement of wooden low-rise buildings occurred mainly in the period after 1917. New larger buildings were very different from the architecture of the eastern side of the old city. The western marginal area of the beginning of the XIX century to the present time keeps a separating function between the city quarters of the historic centre of different architecture and scale of neighborhoods. Not by chance there existed ideas in some projects of the late twentieth century to unite the garden, the square, Surikov's Square, located further to the north and the garden of the merchant Yudin in Kacha in Krasnorayska, a single element of water and green diameter (architect V. I. Krushlinskyi). Governor A. P. Stepanov protested against the anticipated new construction on the slopes and in the floodplains of the Kacha and Yenisei rivers, formally proposed in the master plan of 1827 , believing that one should not provoke flooding of buildings, and landslides of the 
banks. Perhaps, this is why until the early twentieth century, the valley of the Kacha on the northern fringe of the city with suburban villas, remained a beautiful area and favorite rest place of citizens.

The railroad passed at the foot of Nikolaevskaya Hill on the western outskirts of the territory of the late XIX century, by softly rounding Afontovo Hill, cutting a steep slope from the city. Railway repair workshops, warehouses and goods yard were implemented in residential development. As a result, on the western margin a multifunctional area with a high density was developed. In the city the railway line became a formidable anthropogenic transport-industrial boundary. Karaulnaya hill and the Kacha river became natural barriers for the city development in the North. At the time of designing a new master plan of 1936 the valley of Kacha had been built by inexpressive buildings of a mixed use: individual residential development, warehouses, workshops, small industries, municipal areas, industrial bases, etc., Pokrovskaya village to the north of the chapel became one of the areas of the city. The former recreational borderland area loses its importance. To date, the mountain has been exposed to the onslaught of various utility companies, garages, clinging to its base on the west side. In master plans of 1936, 1948, 1973 and 1996 proposals were made for the reconstruction and rehabilitation mode recreational areas. The valley of the "home" river is gradually changing, multifunctional public buildings of citywide importance are appearing, small parks connect the old town and the former district of Pokrovskaya village. It can be argued that the Northern borderland of the historical territory of Krasnoyarsk is gradually changing its structure, returning back to its original importance, but with a new architectural quality - to become a linear public recreational center of the city in the valley of Kacha, at the foot of the Karaulnaya Hill between the historic city and the new northern regions.

Krasnoyarsk was founded and developed in sharply contrasting geographical conditions and the form of the city plan followed them. Marginal areas, their contours, also

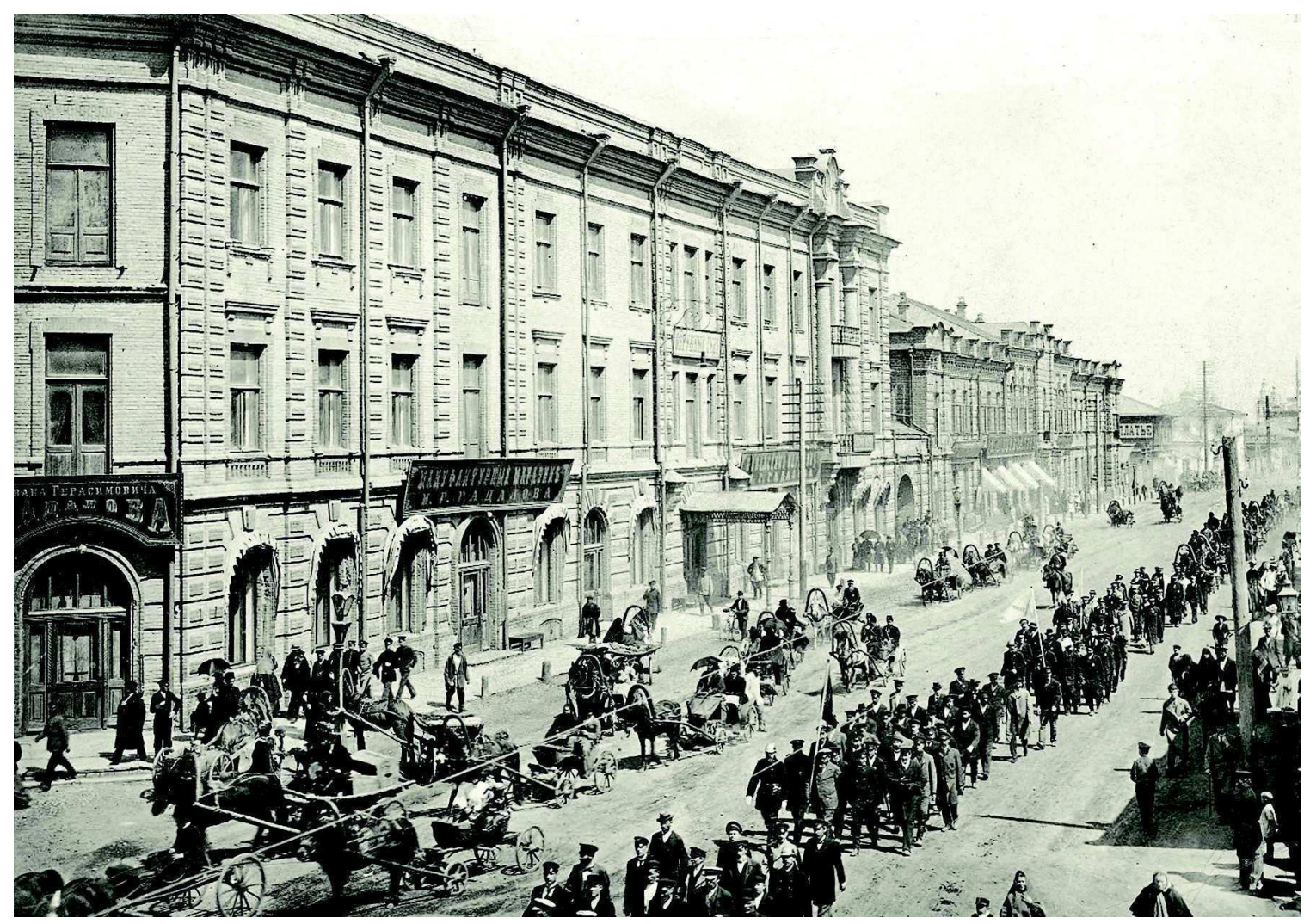

Figure 2.

Old blocks of Krasnoyarsk. 


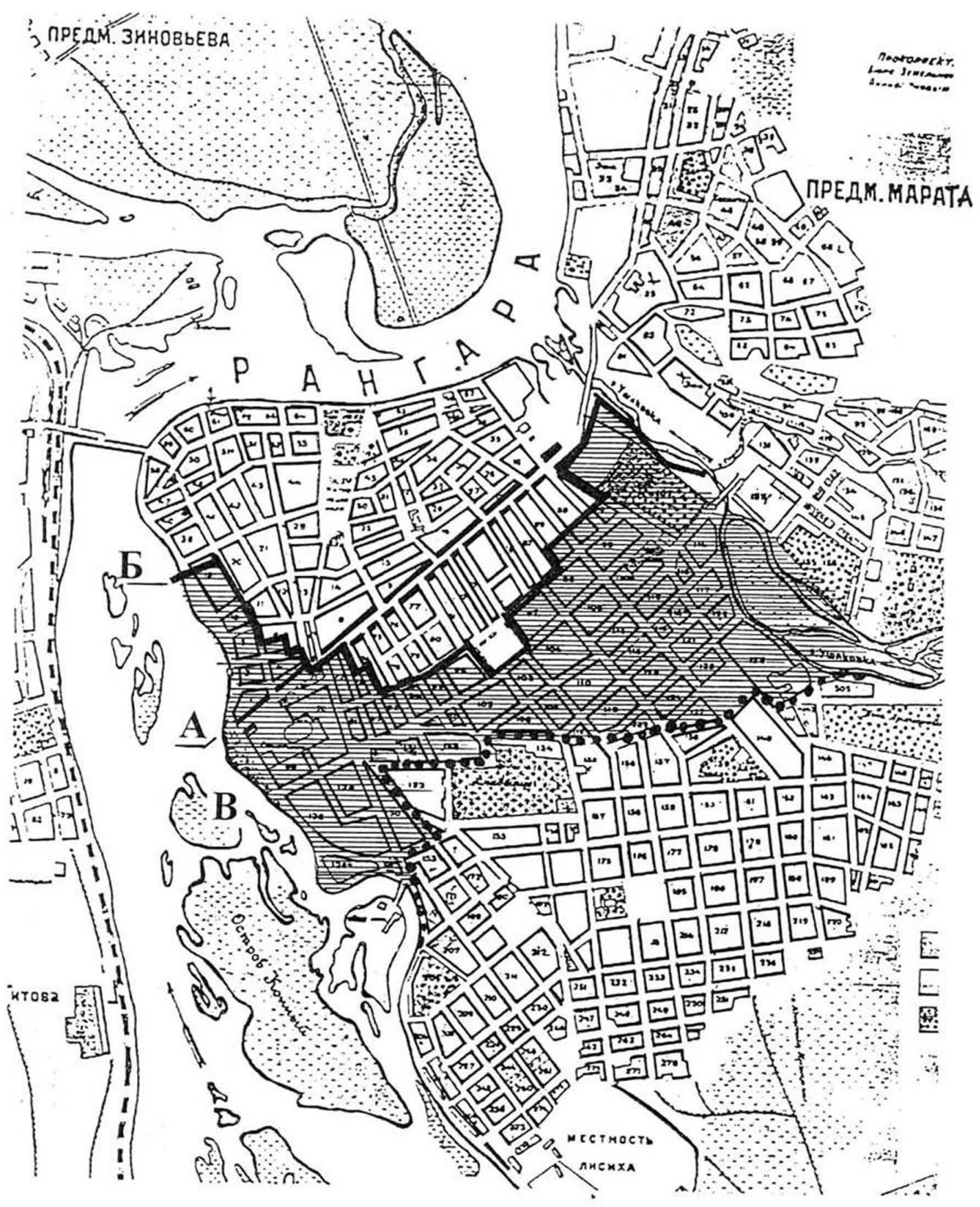

Figure 3.

Scheme of the old Irkutsk

followed the pattern of the landscape, being preserved in the modern structure of the city, but now as internal morphological units, separating the historic center and other areas of the city. Former marginal areas of the old town have changed or are in the process of planning structure change, but retained their importance of buffer areas (with a dual nature: a transitional importance and a separating character) between the development and natural components, between the residential and industrial development and between the development of different architectural quality.

The nearest city to Krasnoyarsk - Irkutsk can be considered as a contrast example of the formation of the city, under the influence of a single global forces and technologies. 
Irkutsk ostrog (founded in 1661) in 1682 became the center of an independent province (voevodstvo), which in 1686 received the city status. It is of interest to note that even in the 50-70ies of the XX century during a period of intense industrial construction Irkutsk was the only city in Siberia, in the borders of which there were no large industrial enterprises and at the beginning of the XVIII century consisted of "small" and "large" cities. A "small" town was a wooden jail on the territory of which were concentrated an administrative building and the home of the Voevoda, then the Governor and officials. It was not only the administrative center of the city, but also of the extensive province. The ostrog was rebuilt and expanded twice in 1669 and 1693, was conveniently located on the crossroads of trade and colonization routes. So very quickly there appeared a"big" city - posad - a marginal territory of Irkutsk of the period, which was gradually inhabited by alien people, mainly by the people from the Russian North. The posad gradually embraced a "small" city, expanding in three directions to the South and South-East of the Angara. The economic life of the province concentrated here. During this period of construction, the low floodplain area crossed by logs and dead channels of the Angara tributaries was being developed without administrative and planning regulation. Decisions as to where, what and how to build were made only by homeowners, for reasons of personal expediency. The areas not liable to flooding were chosen, there were no streets, and the south window location was the only rule of construction orientation. Perhaps, construction was affected by the method, adopted in the Russian North - the picturesque chaos of the houses actually prevented the building from through blowing in cold winter. Later, formed by driveways, streets actually repeated the outlines of the coastlines of the Angara and Ushakovka. For example, there was an unsuccessful attempt to straighten Basmanskaya Street (now Sverdlova) in the process of development regulation, but it presumably ran around the edge of the log formed by a creek of one of the tributaries of the Angara - Gryaznushki. Disproportionate picturesque web of streets of the marginal area of Irkutsk of the XVIII century in a generalized form has survived to the present time till the Street of Karl Marx, has become the compositional planning "frame" in the oldest part of the historical centre of the city. Defensive fortifications - "polisads" (artificial/physical border) erected in 1726 (in modern Karl Marx Street), became a border of the fringe area (of a "big" city). Behind these borders the barracks of the local garrison, named "soldier's grid" were located and once again unplanned development appeared. An active

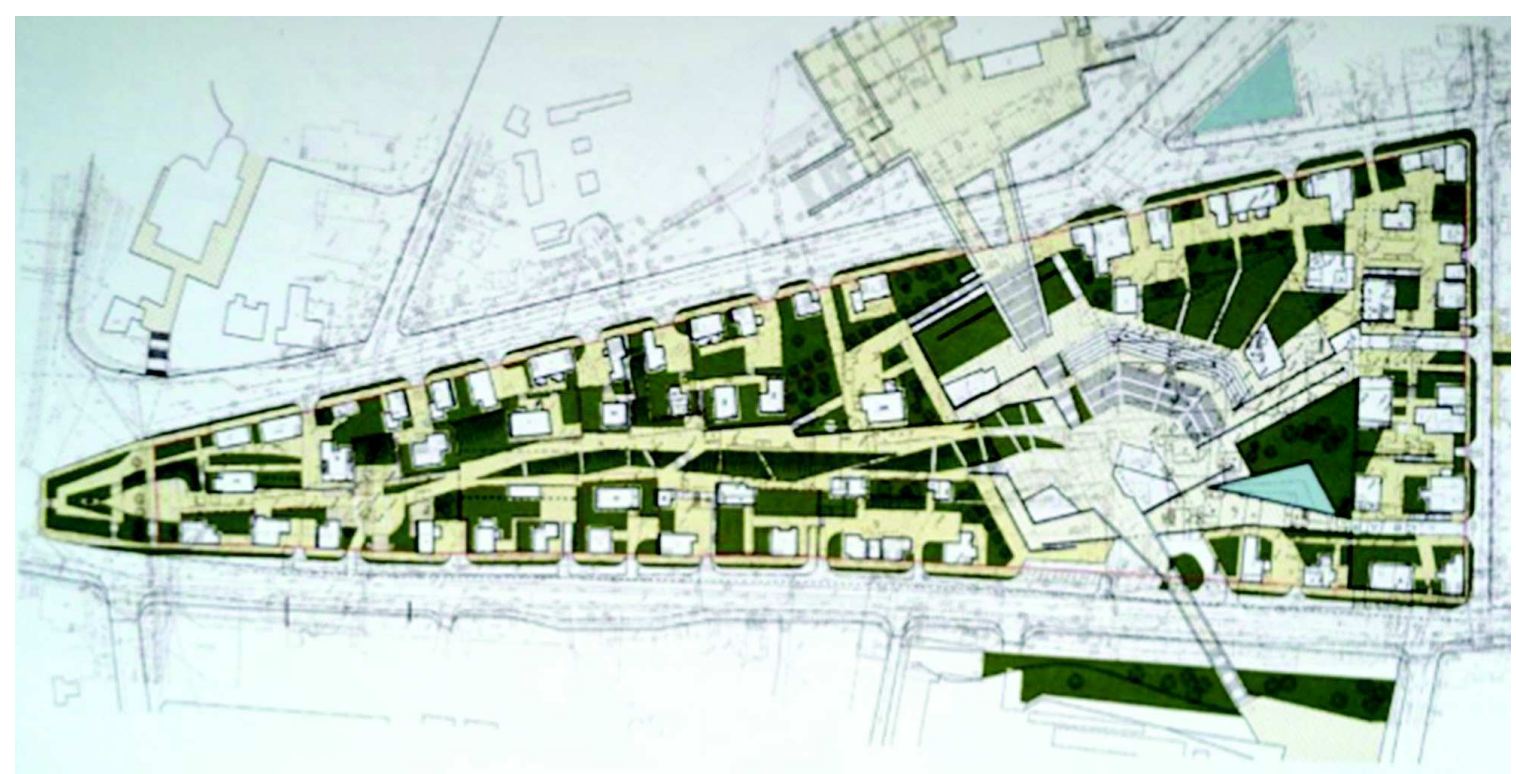

Figure 4

Block 21. Irkutsk. Plan 
growth of the city occurred after the formation of the Irkutsk province in 1764. There was an increase in areas of the city due to the growth of the next ring of marginal territories and the main direction of development of the city to the south-east towards the Krestovozdvizhenskaya Mountain was being determined. In the first master plan, adopted in 1792, attempts were made to straighten the pattern of streets, to order their width; a regular design of new neighborhoods was considered. But it turned out to be impossible to resolve the discrepancy between the axes to the "palisade" city and the new one. Moreover, when fortifications were dismantled, a complete mismatch of the alignments of streets in the old city and outlying blocks was revealed. Attempts to reschedule the "big" city in the regular one failed even after the fire of 1879, when almost the whole of its development with few exceptions had perished in the fire. The city was very quickly rebuilt within the boundaries of the previously established blocks. It became possible only to unscramble the size of the streets to some extent. In 1899 a new approved master plan of Irkutsk legalized this situation. According to the master plan of 1792 all industrial enterprises, factories, plants, slaughterhouses were supposed to be positioned downstream of the Angara river in the Znamenskii suburb, residential area - on flat area till the Jerusalem Mountain. So for the first time in the history of Irkutsk a sort of functional zoning with the allocation of industrial economic fringe was held. This vast territory of "brick sheds" has been preserved to the present day on the banks of the Angara river at the foot of the Jerusalem Mountains. In the aftermath of the fire, because of the shortage of housing, the construction of two and more residential houses on a plot of one estate became conventional; housing density increased significantly. In the early $\mathrm{XX}$ century, this density did not allow new mass construction in the old town. According to $\mathrm{N}$. Bubis the most important factor that allowed Irkutsk to maintain uniform integrity of the historic central part was the split of plots on the outskirts, cutting off significant

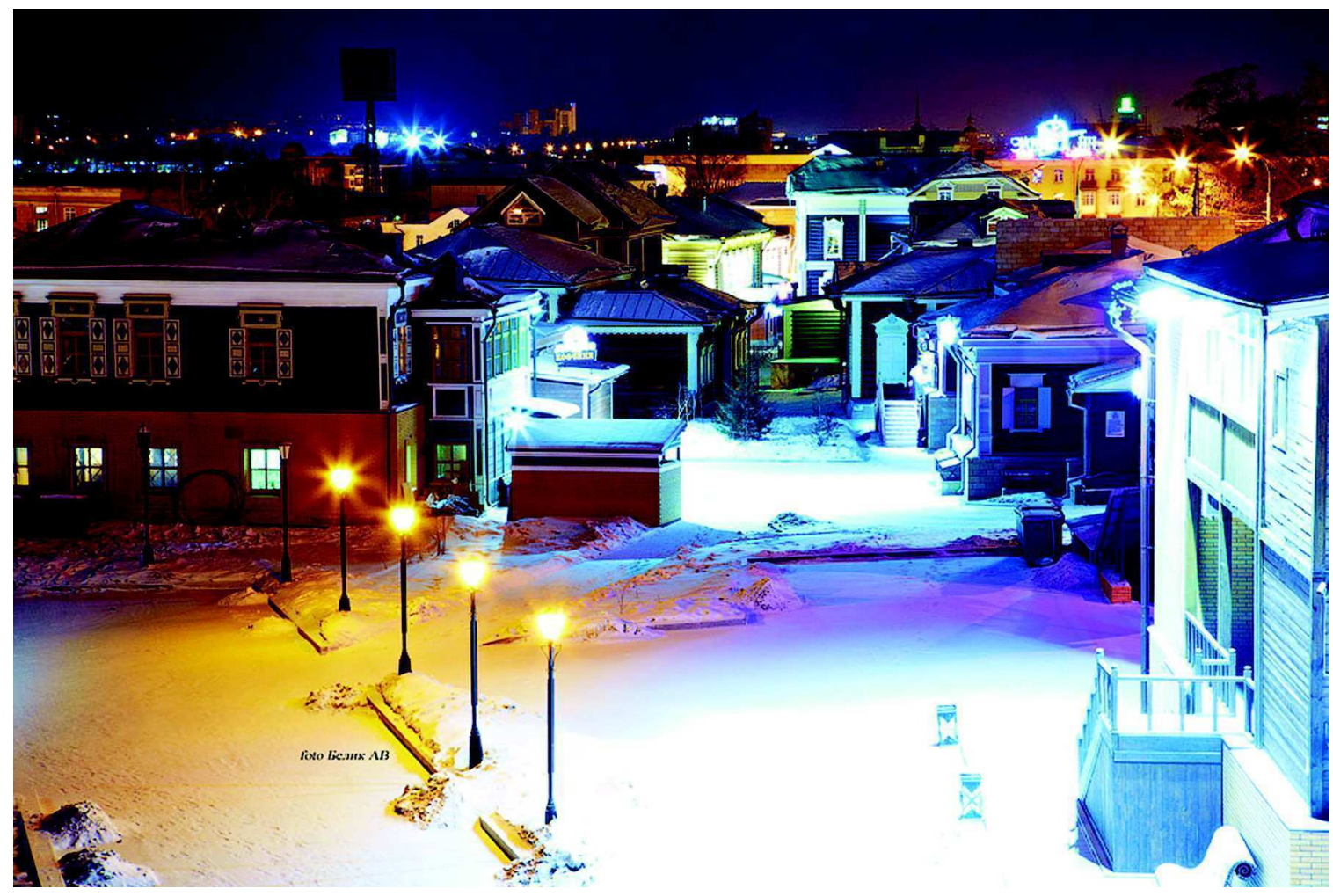

Figure 5.

Block 21. Irkutsk.

Images http://www.i-irk.com/gallery/foto_irkutska_130_kvartal/ Photo A. B. Belik 
undeveloped areas and mixing of old and new buildings. On the other hand, it is on the outskirts of the late XIX century where most old buildings, the most valuable architectural fund not killed in the fire of 1899 have been concentrated now. By the end of the first third of the XIX century the city "greeted" on its way of development an insurmountable barrier for development of construction technologies - Krestovozdvizhenskaya Mountain; that is why the last row of blocks, located along the line of streets Podgornaya - Gornaya - Kanavnyi Pereulok received an incomplete triangular shape. This planning grid, in somewhat modified manner, has been preserved to the present time. According to the testimony of Irkutsk chronicle in the 1840ies the city "leapfrogged" the steep slope and built the mountainous Ushakovo part as far as Arhireysky Villa (Dacha). It should be noted that only by the end of the XIX century, there had been some alignment of this part of the city: having mastered the territory between the Angara and the Jerusalem cemetery, Irkutsk, stopped by a difficult terrain, for nearly half a century slowed his development to the south. Fringe areas have played a preservative role in urban Irkutsk history: established in the XVII-XVIII centuries and reaching "palisade" they have formed a vivid planning drawing of the old town of the preplanned period; an increased development density after the fire has become the cause of preserving the integrity of this part of the city; the "soldier's grid" along with the buffer zone, reaching the slopes of the Jerusalem mountains have become the outskirts of the territory established in the XVIII-XIX centuries. It is the most valuable construction, not affected in the fire of 1879 , and at the same time it is the most contrasting development due to the introduction of new construction on cut off areas. A physical boundary - "polisad" military fortifications - has formed the modern K. Marx street, because due to a discrepancy between the alignments of freely developed outlying areas, transport links between the "big" city and behind the polisad part is made possible only by a transverse line of the former line of fortifications.

When comparing the history of the formation of fringe belts of Krasnoyarsk and
Irkutsk, large cities of Siberia in the period up to the beginning of the XX century, their role has become apparent in the formation of the city spatial composition; dependence of the planning pattern both of the city and its outlying territories on geographical conditions, changing administrative status, industrial development in each new period of development. Towns and cities consistently use or adapt to natural boundaries and barriers or new artificial/physical boundaries are built. After the cities lose their defensive importance, industrial, engineering, transport structures and their combinations serve as barriers comparable to the scale of the city and the level of construction technologies. Fringe areas appear at the boundaries/ barriers and gradually "surround" the city, being transitional to the natural environment. Step by step unique landscape units form within the town fabric. The newly adopted master plans contain drawings and building rules for new neighborhoods (suburbs, regions), realized, as a rule, close to design decisions; master plans contain as well drawings and actions on streamlining the current established outlying territories, which are implemented, as a rule, only partially.

The samples of the renovation of the valley of the river Kacha at Krasnoyarsk and recreation of the Block 21 at Irkusk could be considered as the flexible incorporation into the historic complicated and highly contradictory dialectic territories between old and modern understanding of the town environment. "New" river valley keeps traditional functioning of the inner fringe belt of Krasnoyarsk and modern architectural form. Re-created Block 21 at Irkutsk in historical form got a new using. Both identify old towns in modern city life.

\section{Conclusion}

Taking into account historical knowledge of the urban from development city must be built or restored as an ongoing system - from central areas to the most remote communities. There exists a method of establishing highly conventional boundaries of natural areas - "a sense of place" of local residents, confirmed 
by the territory use zoning plan. In domestic practice of urban designing, plans at different levels contain a number of documents substantiating certain boundaries of functional areas, structural parts of the settlement, land allocation for roads, plans of surveying, red lines of development, etc. Conventional boundaries require the functional integrity of the process, planned on the "circled" area, but do not assume any connectivity of neighboring territories or unplanned variability of the areas highlighted in the project, and these factors do not assist to the formation of the whole urban environment. In this way functional, composition, natural-anthropogenic and other conflicts of neighboring areas are laid. Research in the field of urban morphology allows to explain the formation of spatial gaps, borders of heterogeneous territories, and established unique regional features of both historical towns and certain districts of the city. On the other hand, the growing factual study of cities research in different countries confirms the universality of the laws of urban development and this could be used in modern projects of renovation of cities.

\section{References}

Barke, M 'Morphogenesis, fringe belts and urban size: an exploratory essay' in Slater, T.R. (ed.) The built form of Western cities (Leicester University Press, Leicester), 1990, 279-99

Barke, $M$ 'Land use succession: a factor in fringe-belt moification' Area 8, 1976, 303-6

Bubus, N. 'Origin and main stages of the Irkutsk development' History of Irkutsk № 4, 2001, 2-7

Conzen, M.R.G. Alnwick, Northumberland: a study in town-plan analysis. George Philip, London. Institute of British Geographers Publication, 27, 1960, $135 \mathrm{p}$.

Panov, E. M. 'Stone Chronicle', Krasnoyarsk and citizens of Krasnoyarsk, 1978, 115 p.

Tsarev, V.I., Krushlinskyi V.I. 'Krasnoyarsk. History and urban development' Klaretianum, 2001, 252 p.

Whitehand, J.W.R. 'Fringe belts: a neglected aspect of urban geography', Transactions of the Institute of British geographers, 41, 1967, 223-33

Whitehand, J.W.R. 'The changing nature of the urban fringe: a time perspective', in Johnson, J.H. (ed.) Suburban growth (Wiley, London), 1974, 31-52

Whitehand, J.W.R. 'Urban fringe belts: development of an idea', Planning Perspectives 3, 1988, 47-58

Ünlü, T. 'Thinking about urban fringe belts: a Mediterranean perspective' Urban Morphology. Vol.17. № 1, 2013, 5-20 